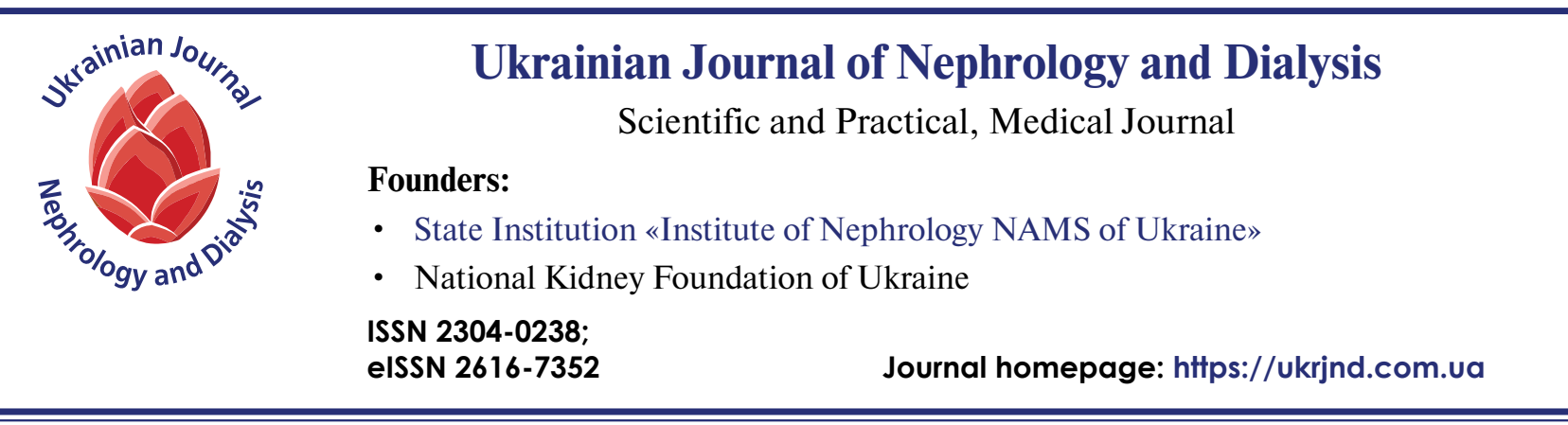

\section{Clinical case reports}

doi: 10.31450/ukrjnd.2(70).2021.02

\section{Ergün Parmaksız, Meral Meşe}

\section{Fabry disease: a single-center experience}

University of Health Sciences, Kartal Dr Lütfi Kirdar Training Hospital, Istanbul, Turkey

\section{Citation:}

\section{Article history:}

Received June 9, 2020

Received in revised form July 16, 2020

Accepted July 19, 2020
Parmaksız E, Meşe M. Fabry disease: a single-center experience. Ukr J Nephr Dial. 2021;2(70):13-18. doi: 10.31450/ukrjnd.2(70).2021.02

\begin{abstract}
Fabry disease (FD) is an inborn X-linked lysosomal storage disorder resulting from $\alpha$-galactosidase $A(\alpha-G a l)$ activity deficiency in lysosomes. This results in the accumulation of particularly globotriaosylceramide (Gb3) within lysosomes in a wide variety of cells. This study aimed to analyze the clinical presentation, findings and family screenings of index cases, management and outcomes of FD patients in our center.

Methods. Data including demographic characteristics, personal history of comorbidities, laboratory findings at the time of diagnosis were recorded. $\alpha-$ Gal activity was measured in all males and females as initial analysis. The cut-off trigger was determined as 1.2 mmol/L per hour. Mutation analysis was performed in males and females with decreased $\alpha-$ Gal activity as a diagnostic assay. In addition, mutation analysis was performed change in females with normal $\alpha-$ Gal providing they have clinical signs or family history for $F D$.
\end{abstract}

Results. The individuals from nine FD families were presented.

Conclusion. Screening for genetic diseases such as FD has crucial conclusions. The detection of FD in an index case leads to appropriate therapy for that patient. Family screening can be started and additional undiagnosed individuals can be detected.

Key words: Fabry disease, $\alpha$-galactosidase A, proteinuria.

Conflict of interest statement: The authors declare no competing interest.

(C) Parmaksız E., Meşe M., 2021. All rights reserved. Correspondence should be addressed to Ergün Parmaksı: drergnprmksz@hotmail.com 
(C) Пармаксиз Е., Меше М., 2020

УДК: 575.1:616-056.7]-07

\section{Ергюн Пармаксиз, Мерал Меше}

\section{Хвороба Фабрі: досвід одного центру}

Університет наук про здоров’я, навчальний госпіталь ім. Карталя Лютфі Кірдара, Стамбул, Туреччина

Резюме. Хвороба Фабрі (ХФ) - це Х-зчеплена лізосомна хвороба накопичення, яка викликається мутаціями у гені GAL A, що призводять до недостатньої активності $\alpha$-галактозидази А, накопичення глікосфінголіпідів та небезпечних для життя ускладнень. Метою цієї роботи було проаналізувати клінічну картину, наслідки та результати лікування хворих на ХФ у нашому центрі.

Дані, включаючи демографічну характеристику, анамнестичні дані щодо супутніх захворювань, лабораторні дані на момент встановлення діагнозу ХФ були проаналізвані та представлені. У якості діагностичного тесту використовували аналіз мутації гену $\alpha$-GAL А у чоловіків та жсінок зі зниженою активністю $\alpha$-Gal. Крім того, аналізували мутації у жінок з нормальним $\alpha$-Gal, за умов наявності клінічних ознак або сімейного анамнезу ХФ.

У роботі представлено клінічну характеристику та результати сімейного скринінгу пацієнтів з ХФ.

Ключові слова: хвороба Фабрі, $\alpha$-галактозидаза А, протеїнурія.

Introduction. Fabry disease (FD) is an inborn $\mathrm{X}$ linked lysosomal storage disorder resulting from $\alpha-$ galactosidase A ( $\alpha$-Gal) activity deficiency in lysosomes [1]. Several mutations in the GLA gene located in the position Xq22 may cause decreased $\alpha$-Gal activity. This results in the accumulation of particularly globotriaosylceramide $(\mathrm{Gb} 3)$ within lysosomes in a wide variety of cells. Accumulation of Gb3 in the vascular endothelium leads to microvascular obstruction and ischemic tissue injury in various vital organs such as kidney, heart and nervous system $[2,3]$.

Variable enzymatic activity leads to a wide spectrum of clinical manifestations in hemizygous patients. Moreover, clinical manifestations of FD are highly heterogeneous depending on random X-chromosomal inactivation in females [4].

The estimated prevalence of FD in males ranges between 1/40000 and 1/117000 [5]. But the precise prevalence is unknown due to female carriers and males with the atypical disease. FD is known as a rare or orphan disease. However, a higher prevalence of FD was reported in specific populations such as patients with chronic kidney disease and/or left ventricular hypertrophy and/or stroke.

Leukocyte $\alpha$-Gal activity as the initial diagnostic assay is used in all males. Genetic mutation as an initial assay is recommended in females due to the fact that levels of $\alpha$-Gal A activity can overlap with levels found in controls.

Childhood intense and disabling neuropathic pain (acroparaesthesia), angiokeratomas, hypohidrosis, abdominal pain, postprandial diarrhea, corneal and len-

Ergün Parmaksız drergnprmksz@hotmail.com ticular opacities and mortal late complications as the involvement of kidneys, heart, and brain [6] are the clinical features of FD. Fabry nephropathy including podocyte injury, proteinuria, and Fanconi syndrome, might progress to end-stage renal disease throughout the fifth decade of life [7] before enzyme replacement therapy (ERT). Progression of kidney disease slows effectively with ERT in Fabry patients who are especially in the early stages of Fabry nephropathy [8].

On the other hand, most of the females involve delayed onset of symptoms and milder progression. However, some of them with $\mathrm{X}$-chromosomal inactivation may present with severe clinical signs similar to those seen in classically affected male patients.

Earlier diagnosis and initiation of treatment would be expected to extend survival compared to the era before ERT [9].

In terms of treatment, the main goal is to replace the missing or deficient enzyme (alpha-galactosidase A, or $\alpha$-Gal). Patients, especially at an early phase of the disease, may get significant clinical benefits from enzyme replacement therapy (ERT), such as beneficial effects on the heart, kidneys, pain, and quality of life [10].

This study aimed to analyze the clinical presentation, findings and family screenings of index cases, management and outcomes of FD patients in our center.

Materials and Methods. Study design. Hospital records were evaluated retrospectively from 2006 to 2019. That was a case series observational study, population-based with design close to analytic historical cohort study (particularly longitudinal).

Data collection. Data including demographic findings (age, gender), personal history of comorbidities (chronic kidney disease, diabetes mellitus, systemic hypertension), laboratory findings (serum urea, creatinine, glucose, sodium, potassium, albumin, hemoglobin, white blood cell, platelet counts) at the time of diagnosis were recorded. 
The urine sample was also evaluated. Proteinuria is defined as the presence of proteinuria which is discovered by the use of a dipstick during urinalysis. If proteinuria was detected, 24-hour urine sample was collected to find the degree of proteinuria. Normal range proteinuria was defined as proteinuria below $150 \mathrm{mg} /$ day. Microscopic hematuria is defined as the excretion of more than two red blood cells per high-power field in a centrifuged urine specimen.

Diagnostic Tools. A-Gal activity was measured in all males and females as initial analysis. Since there might be false-positive results with dried blood sample (DBS) [11], we used the cut-off trigger as $1.2 \mathrm{mmol} / \mathrm{L}$ per hour. This cut-off point was determined from the ROC testing by the Archimed Life Science laboratory in the center.

In our families, sequence analysis was used as molecular testing method. Mutation analysis was performed in males and females with decreased $\alpha-$ Gal activity as a diagnostic assay. In addition, mutation analysis was performed in females with normal $\alpha$-Gal providing they have clinical signs or family history of FD. However, we diagnosed FD with low $\alpha$-Gal activity and clinical signs in some patients without genetic tests due to some technical problems in the laboratory during that period. In addition, enzyme activity and clinical signs had been used for diagnosis in some other patients before the introduction of mutations commercially to the clinic. Standard questions were used to collect data on patients with suspected FD (Table 1).

In addition, cardiological, ophthalmological, ear and neurologic examinations of these patients were performed by specialists. Index case was defined as the first identified case in a group of related cases of FD. Relatives of index cases were observed according to the procedure.

Table 1

Questionnaire for patients with suspected FD

\begin{tabular}{|l|l|}
\hline Acroparesthesia & \\
\hline Telangiectasia,angiokeratoma & \\
\hline Heat, exercise intolerance & \\
\hline Hypo- or hyperhidrosis & \\
\hline Mouth dryness & \\
\hline Stroke history & \\
\hline Hearing impairment & \\
\hline Frequent abdominal pain, Diarrhea & \\
\hline
\end{tabular}

FD patients with/without ERT were followed up periodically in our outpatient clinic for one to five years.

Results. A total of 56 (38 female/18 male) individuals were evaluated. The cut-off trigger was $1.2 \mathrm{mmol} / \mathrm{L}$ per hour for DBS. Thirty-eight (20 female and 18 male) individuals had low $\alpha-$ Gal activity. We performed mutation analysis for these 30 patients. In addition, we did the mutation analysis for 18 females who had any symptoms without low $\alpha-\mathrm{Gal}$ activity. We detected mutation in 35 (22 female and 13 male) patients. We diagnosed Fabry disease in 8 symptomatic patients with low -Gal activity before the introduction of mutations commercially to clinicians. The ratio of FD was $76.7 \%$.

The individuals' characteristics in each FD family are presented below.

\section{Family 1:}

R.U., a 56-year-old man, the index case, was the father of the family. He was screened during the maintenance hemodialysis program and $c[427 \mathrm{G}>\mathrm{A}]$ [P.[A143T] mutation was detected. In terms of his family screening, mutation at the same locus was detected in both his spouse (consanguineous marriage) and is children. Family pedigree is shown in Figure 1.

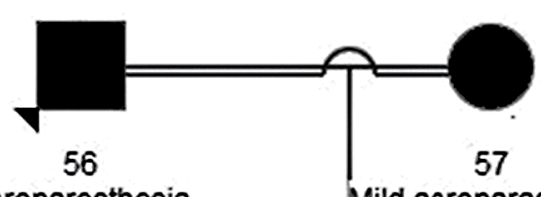

Acroparesthesia Mild acroparasthesia

Syncope attacks Follow up without ERT Symptoms resolved under ERT

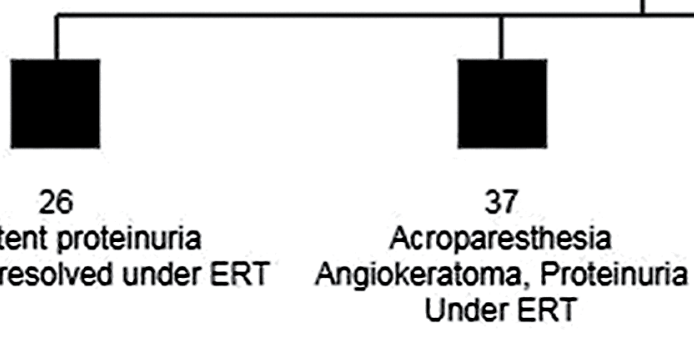

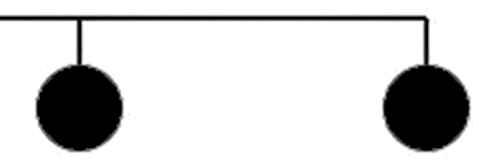

31

Proteinuria

Under ERT for a while Lost to follow up
38

Maculopapular lesions Under ERT for a while Lost to follow up

Fig. 1. Pedigree of the family with ages of the members. 


\section{Family 2:}

F.A., a 25-year-old woman, was the index case in this family. She presented with persistent microscopic hematuria. She had a normal renal function without proteinuria. Diagnostic examinations for hematuria were clear. However, the mutation ( c.427G $>A(p$. A143T) (p. Ala143Thr) (heterozygous) consistent with FD was detected. This mutation previously was detected in patients with late-onset FD [12]. She has been followed up with ERT since 2017.

23 individuals could be screened in her family and 12 patients had the same mutation. We found such a high prevalence in this family due to the fact that endogamy was very high in her family.

Her mother and father were relatives. In addition, her maternal aunts married her paternal uncles and her maternal uncles married her paternal aunts.

S.A., an 18-year-old man, was one of the cousins of F.A. He had the same mutation with low $\alpha-\mathrm{Gal}$ activity. He had a normal renal function with normal range proteinuria. Tortuosity of conjunctival and retinal vessels was detected in his ophthalmological examination. He had also persistent acroparesthesia. ERT was planned to be started for this patient.

Regarding 10 female individuals, five of them had microscopic hematuria, three of them had a tortuosity of conjunctival and retinal vessels; two of them had mild acroparesthesia. Cardiologic examinations of all of them were normal. None of them had proteinuria. They were lost to follow up due to social conditions.

\section{Family 3:}

A.T., the index case, had nephrotic range proteinuria with tortuosity of conjunctival and retinal vessels. Hemizygotes. L275F $(\mathrm{C}>\mathrm{T})$ mutation was detected. ERT could be started after transplantation. We extended family screening. Two brothers of index cases died due to complications of renal failure before ERT. Most of the individuals' complaints gradually improved after ERT. The family pedigree is shown in Figure 2.

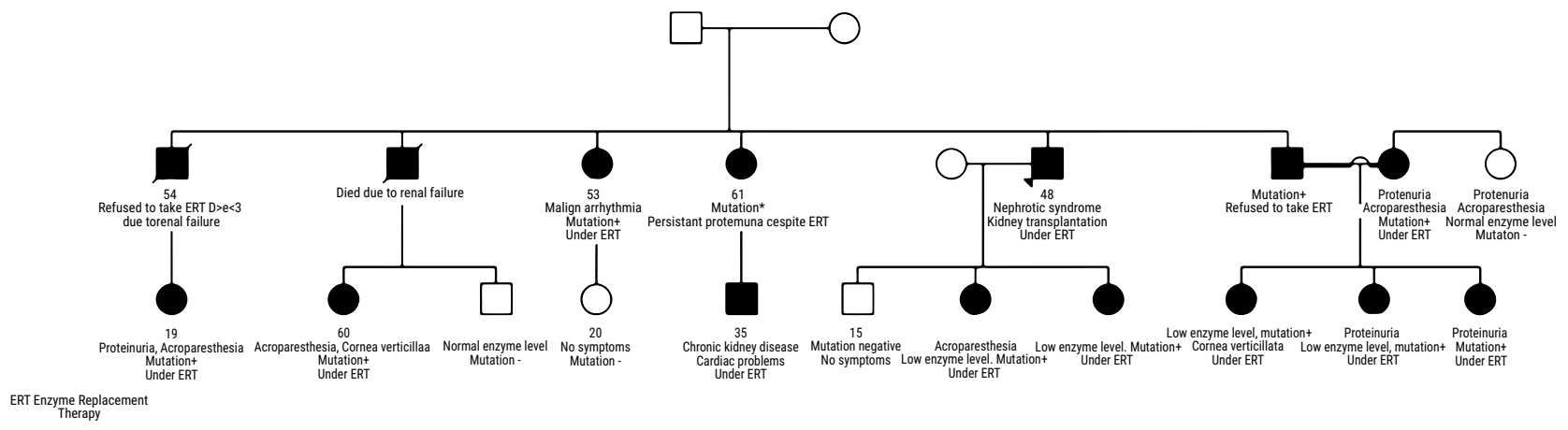

Fig. 2. Pedigree of the family with ages of the members

\section{Family 4:}

F.B., a 45-year-old woman, whose sister was the index case with low enzyme activity on hemodialysis treatment, had proteinuria and hypertension. ERT treatment was initiated.

Ş.B., an 18-year-old girl, sister of F.B, had proteinuria since she was 9 years old. She had low enzyme activity. Her biopsy revealed electron-dense deposits by the electron microscope. Her proteinuria regressed gradually with ERT.

\section{Family 5:}

F.E., a 53-year-old woman; her grandmother was a hemodialysis patient, her mother turn out to be the index case and was a peritoneal dialysis patient. She had proteinuria with low enzyme activity. ERT was initiated.

F.E., a 20-year-old girl, daughter of F.E., had Swyer syndrome with moderate mental retardation. She had proteinuria with low enzyme activity. After starting ERT, her proteinuria regressed and her mental situation partially developed, gradually.

\section{Family 6:}

N.C., a 33-year-old woman, presented with acroparesthesia, chronic kidney injury with proteinuria. She demonstrated a low enzyme level. She has gotten ERT for 2 years. Her kidney functions gradually improved under ERT despite two pregnancies during that period.

A.B., 8 years old, daughter of N.C, had proteinuria with the confirmed mutation. She has been followed up by pediatricians without ERT for 2 years.

\section{Family 7:}

D.G., a 20-year-old man, had low enzyme level and proteinuria. His family screening (his two sisters and two brothers) was negative for FD. He has been initiated ERT.

\section{Family 8:}

M.B., a 52-year-old man with proteinuria. He refused to take ERT despite the presence of the mutation and low enzyme level.

\section{Family 9:}

G.Ö., a 42-year-old woman with proteinuria, acroparesthesia and multiple sclerosis symptoms such as persistent headache. RT could not be initiated to her due to normal enzyme levels with lack of mutation. We believed that this was a Fabry patient tough we could not find any mutation by sequence analysis. In terms of this patient, there may be a missing pathogenic variant detectable by just gene-targeted deletion/duplication analysis. 
Discussion. FD is one of the most seen lysosomal storage disorders. It can affect a broad range of vital organs such as kidneys, heart, and brain. However, the disease was always overlooked by clinicians due to nonspecific symptoms and lack of awareness among clinicians. Therefore, FD is usually diagnosed approximately with a delay of 20 years [13].

There is no cure for this disease. However, ERT with the early diagnosis may prevent $\mathrm{Gb} 3$ accumulation before impairment of vital organs. Therefore, detection of the index cases may lead us to find undiagnosed patients by family screenings.

The mean endogamy ratio in Turkey is $23.2 \%$ regarding the data published in 2017 by the Turkish Statistical Institute [14]. 43 from 71 family members were affected in the study of Yalin et al [15]. Therefore, we tried to screen family members of index cases as much as we can. However, in terms of social facts of our country, some family members especially male individuals refused to be screened due to concerns and ignorance of genetic diseases. Parallel to this, some of the patients gave up treatment and lost to follow up. In addition, we could not initiate ERT to four individuals due to social security problems.

Our second family was one of the interesting families in our data in terms of endogamy. All of these family members married their relatives. Only one family member married a non-relative individual.

Regarding twenty three screened family members for Fabry disease, we detect mutation in $12(52,1 \%)$ individuals.

In addition, we could not screen at least half of the family members due to concerns about genetic diseases. Therefore, the ratio of FD would be possibly higher if we could complete all the screenings of the family members.

Regarding the third family, S.S. was far relative to the index case (see Fig 2). She had proteinuria, acroparasthesia and multiple sclerosis symptoms. ERT could not be initiated to her due to normal enzyme levels with lack of mutation. We believe that there are still unknown unique mutations in our country due to high endogamy rates. Since ERT is very expensive, we did not have a chance to give at least one dose of treatment in order to see a response without health insurance.

Our fourth and fifth families had low enzyme activity with nephrologic manifestations of FD despite the presence of detected any mutation. ERT gradually improved their symptoms. The molecular genetic testing method used in FD is either sequence analysis or genetargeted deletion/duplication analysis. The proportion of probands with a pathogenic variant detectable by sequence analysis is $95 \%$. Identification of gene-targeted deletions/duplications by Multiplex Ligation-dependent Probe Amplification (MLPA) could be used if the previous method is failed [16]. In our families, sequence analysis was used as molecular testing method. Therefore, we might miss some pathogenic variants detectable by just gene-targeted deletion/duplication analysis.

FD may affect vital organ systems including the central nervous system. The risk of developing neuropsychiatric symptoms is increased in FD [17]. Regarding members of the fifth family, one of them had mental problems possibly due to FD. Her symptoms gradually resolved after the introduction of ERT.

Inactivation of the $\mathrm{X}$ gene is random as mentioned in the Lyon hypothesis, therefore in some women, severe disease may be seen [18]. In our clinic, we detected female individuals with persistent proteinuria and/or chronic kidney disease in line with this data.

Diagnosis of FD is typically confirmed by biochemical and/or molecular genetic testing. Over a thousand mutations in the GLA gene have been identified $[19,20]$. However, enzyme activity had been used for diagnosis before the introduction of mutations commercially. Therefore, we diagnosed FD with just low enzyme activity and clinical signs and then started treatment in some families.

Conclusions. Screening for genetic diseases such as FD has crucial conclusions. First, the detection of FD in an index case leads to appropriate therapy for that patient. Second, family screening can be started and additional undiagnosed individuals can be detected. Third, genetic counseling can be provided to those patients and the transmission of the disease from generation to generation may be prevented by prenatal screening.

Conflict of interest statement. The authors declare no competing interest.

Authors Contributions.

Ergün Parmaksı: Writing the manuscript, data collection and research management;

Meral Meșe: Data collection and clinical data analysis.

\section{References:}

1. Kint JA. Fabry's disease: alpha. galactosidase deficiency. Science1970;167(3922):1268-9. doi: 10.1126/science.167.3922.1268.

2. Germain DP. Fabry disease. Orphanet $\mathrm{J}$ Rare Dis. 2010;5:30. doi: 10.1186/1750-1172-5-30.

3. Tuttolomondo A, Pecoraro R, Simonetta I, Miceli S, Pinto A, Licata $G$. Anderson Fabry disease: A multiorgan disease. Curr Pharm Des. 2013;19: 5974-96. doi: 10.2174/13816128113199990352.
4. Maier EM, Osterrieder S, Whybra $C$, Ries $M$, Gal A, Beck $M$, Roscher AA, Muntau AC. Diseasemanifestations and $\mathrm{X}$ inactivation in heterozygousfemales with Fabry disease. Acta Paediatr Suppl. 2006; 95: 30-38. doi: 10.1080/08035320600618809.

5. Zarate YA, Hopkin RJ. Fabry's disease. Lancet. 2008; 372: 1427-35. doi: 10.1016/S01406736(08)61589-5. 
6. Pastores GM, Thadhani R. Advances in the management of Anderson. Fabry disease: enzyme replacement therapy. Expert Op in Biol Ther 2002; 2: 325 33. doi: 10.1517/14712598.2.3.325.

7. Porsch DB, Nunes AC, Milani V, Rossato LB, Mattos $C B$, Tsao $M$, et al. Fabry disease in hemodialysis patients in southern Brazil: prevalence study and clinical report. Ren Fail 2008;30: 825-30. doi: 10.1080/08860220802353777.

8. Ortiz A, Cianciaruso B, Cizmarik M. et al. End-stage renal disease in patients with Fabry disease: natural history data from the Fabry registry. Nephrol Dial Transplant. 2010; 25: 769-75). doi: 10.1093/ndt/ gfp554. Epub 2009 Oct 21.

9. Waldek $S$, Patel M, Banikazemi M. et al. Life expectancy and cause of death in males and females with Fabry disease: Findings from the Fabry Registry. Genet Med. 2009;11: 790-6. doi: 10.1097/ GIM.0b013e3181bb05bb.

10. Lidove O, West ML, Pintos.Morell G, Reisin $R$, Nicholls $K$, Figuera LE, PariniR, Carvalho LR, Kampmann C, Pastores GM, Mehta A. Effects of enzyme replacement therapy in Fabry disease - a comprehensive review of the medical literature. Genet Med. 2010 Nov;12(11):668.79. doi: 10.1097/ GIM.0b013e3181f13b75.

11. Finsterer J, Stöllberger C, Voigtländer T. Comparison of two tests for serum alpha-galactosidase in non neuromuscular left ventricular hypertrabeculation/ concompaction. Jpn Heart J 2004;45:179-81. doi: 10.1536/jhj.45.179.

12. Lenders $M$, Weidemann F, Kurschat C. et al. AlphaGalactosidase A p.A143T, a non-Fabry diseasecausing variant. Orphanet J Rare Dis 2016 May 4;11(1):54. doi: 10.1186/s13023-016-0441-z.
13. Mehta A, Beck M, Eyskens F, Feliciani C, Kantola I, Ramaswami $U$, Rolfs A, Rivera A, Waldek $S$, Germain DP. Fabry disease: a review of current management strategies. QJM. 2010 Sep;103(9):641.59. doi: 10.1093/qjmed/hcq117. Epub 2010 Jul21.

14. Turkish Statistical Institute database. Endogamy ratio in Turkey. [Internet]. Available from: www. tuik.gov.tr/ (cited July 15, 2018).

15. Yalın SF, Eren N, Sinangil A, Yilmaz VT, et al. Fabry Disease Prevalence in Renal Replacement Therapy in Turkey. Nephron. 2019 Feb 8;142(1):26-33. doi: 10.1159/000496620.

16. Mehta A, Hughes DA. Fabry Disease. 2002 Aug 5 [Updated 2017 Jan 5]. In: Adam MP, Ardinger HH, Pagon RA, et al., editors. GeneReviews ${ }^{\circledR}$ [Internet]. Seattle (WA): University of Washington, Seattle; 1993-2020. Available from: https://www. ncbi.nlm.nih.gov/books/NBK1292/

17. Mehta A, Beck M, Sunder-Plassmann $G$, editors. Fabry Disease: Perspectives from 5 Years of FOS. Oxford: Oxford PharmaGenesis; 2006.

18. Lyon MF. Gene action in the X. chromosome of the mouse (Mus musculus L.). Nature 1961; 190: 3723. doi: 10.1038/190372a0.

19. Saito S, Ohno K, Sakuraba H. Fabry-database.org: database of the clinical phenotypes, genotypes and mutant $\alpha$-galactosidase A structures in Fabry disease. J Hum Genet. 2011 Jun; 56(6):467-8. doi: 10.1038/jhg.2011.31.

20. Altarescu G, Beeri $R$, Eiges $R$, Epsztejn.LitmanS, Eldar. Geva T, Elstein D, et al: Prevention of lysosomal storage diseases and derivation of mutant stem cell lines by preimplantation genetic diagnosis. Mol Biol Int 2012; 2012: 797342. doi: $10.1155 / 2012 / 797342$. 